\title{
Łukasz DOMINIAK
}

Uniwersytet Mikołaja Kopernika w Toruniu

lukasdominiak80@gmail.com

\section{LIBERTARIANIZM I TEORIA TOŻSAMOŚCI}

\author{
KONCEPCJA NAJBLIŻSZEGO KONTYNUATORA \\ ROBERTA NOZICKA JAKO TEORIA TŁA \\ ZASADY AUTOWŁASNOŚCI
}

ABSTRACT Libertarianism and the Theory of Personal Identity. Robert Nozick's Closest Continuer Theory as a Background Theory of the Principle of Self-Ownership The research problem of the present paper is the following question: May the closest continuer theory serve as a background theory for the principle of self-ownership? This issue is a peculiar instance of the more general problem of the anthropological presuppositions of the libertarian political philosophy that can be phrased in a Kantian manner: How is self-ownership possible?; or in a more detailed way: What sort of entity a human being has to be, if it is possible for him to be a self-owner? The research thesis that is argued for in the paper says that: 1) the closest continuer theory may not serve as a background theory for a wide principle of self-ownership since as an example of reductionist theory of personal identity it excludes the possibility of possessing this set of psychological facts which the personal identity is reducible to and possession of which is presupposed by the wide principle of self-ownership; 2) the closest continuer theory may though serve as a background theory for a narrow principle of self-ownership since this principle assumes that one can own only scarce resources and psychological facts are not instances thereof.

Keywords: libertarianism, self-ownership, closest continuer theory, theory of the person, personal identity over time

Słowa kluczowe: libertarianizm, autowłasność, teoria najbliższego kontynuatora, teoria osoby, tożsamość osobowa w czasie 


\section{WPROWADZENIE}

Problemem badawczym niniejszego artykułu jest następujące pytanie: „Czy koncepcja najbliższego kontynuatora może być teorią tła zasady autowłasności?”. Problem ten zostanie szczególowo wyjaśniony w dalszej części tekstu, w tym miejscu należy jednak zauważyć, że jest on częścią szerszego zagadnienia z zakresu filozofii politycznej libertarianizmu ${ }^{2}$ i jej antropologicznych presupozycji, które można sformułować w kantowskim pytaniu: ,jak możliwa jest autowłasność?”, albo ściślej, „jakiego rodzaju istotą musi być człowiek, skoro jest autowłaścicielem?”.

Tezą, którą stawia ten artykuł, jest następujące twierdzenie: 1) koncepcja najbliższego kontynuatora nie może być teorią tła szerokiej zasady autowłasności, ponieważ jako jeden z przypadków redukcjonistycznej teorii osoby/tożsamości wyklucza ona możliwość bycia właścicielem zbioru tych faktów mentalnych, do którego redukowalna jest osoba/tożsamość, a którego własność zakłada szeroka zasada autowłasności; 2) koncepcja najbliższego kontynuatora może natomiast być teorią tła wąskiej zasady autowłasności, ponieważ zasada ta zakłada, że przedmiotem własności mogą być tylko dobra rzadkie, do takich zaś nie należą fakty mentalne; to zaś nie prowadzi do sprzeczności pomiędzy tym, czego właścicielstwo dopuszcza zasada autowłasności, a czego właścicielstwo wyklucza teoria najbliższego kontynuatora. Twierdzenie to jest jednym z elementów ogólnej teorii osoby/tożsamości ${ }^{3}$ presuponowanej przez zasadę autowłasności; tej ogólnej teorii poświęcone zostało podsumowanie niniejszego artykułu, jakkolwiek

1 Na temat pojęcia autowłasności oraz różnicy pomiędzy autowłasnością a samoposiadaniem zob. D. Juruś, $W$ poszukiwaniu podstaw libertarianizmu w perspektywie Rothbardowskiej koncepcji wtasności, Kraków 2012, s. 78; Ł. Dominiak, Problem aksjomatyczności zasady autowtasności w filozofii politycznej libertarianizmu, „Athenaeum. Polskie Studia Politologiczne” 2016, Vol. 49, s. $42-64$.

2 W niniejszym artykule skupiamy się na libertarianizmie prawicowym, jakkolwiek przedstawione tu rozważania mają także zastosowanie do libertarianizmu lewicowego, który również stoi na stanowisku, że człowiek jest autowłaścicielem. O libertarianizmie lewicowym zob. m.in.: The Origins of Left-Libertarianism. An Anthology of Historical Writings, red. P. Vallentyne, H. Steiner, New York 2000; Left-Libertarianism and Its Critics. The Contemporary Debate, red. P. Vallentyne, H. Steiner, New York 2000; M. Otsuka, Libertarianism without Inequality, Oxford 2003.

3 O związku pomiędzy teorią osoby a teorią tożsamości osobowej w czasie, a także o związkach pomiędzy takimi pojęciami, jak: teoria osoby, koncepcja jaźni, moralna epistemologia, teoria natury ludzkiej, teoria podmiotu moralnego, antropologia filozoficzna, zob. D. Parfit, Reasons and Persons, Oxford 1987, s. 202; M. Sandel, Liberalism and the Limits of Justice, New York 1998, s. 50. W krajowej literaturze przedmiotu pojęcia te zob. inter alia w: B. Wójcik, Bioetyka i tożsamość cztowieka, Tarnów 2007; tenże, Świadomość ponowoczesna i jej krytyka. Funkcjonalizm homunkularny w interpretacji świadomości Daniela C. Dennetta, Kraków 1997, Rozprawy OBI; tenże, Zasady zachowania tożsamości genetycznej i psychicznej jako wyróżnik bioetyki personalistycznej, „Sympozjum” 2002, Vol. 6, nr 1, s. 91-108; tenże, Śmierć mózgu jako kryterium śmierci cztowieka - problematyka filozoficzno-etyczna, „Medycyna Praktyczna” 2007, nr 4, s. 196-199; I. Ziemiński, Życie wieczne. Przyczynek do eschatologii filozoficznej, Poznań-Kraków 2013, Wyktady Otwarte z Teologii Naturalnej im. J.M. Bochańskiego OP, 4; tenże, Metafizyka śmierci, Kraków 2010, Myśl Filozoficzna - WAM; tenże, Moralność i religia. Poglądy filozoficzne Josepha Butlera, Warszawa 2015; Filozofia podmiotu, wybór J. Górnicka-Kalinowska, przeł. B. Chwedeńczuk i in., Warszawa 2001, Fragmenty Filozofii Analitycznej, 8. 
właściwym przedmiotem analizy jest wskazane tu zagadnienie szczegółowe: relacja pomiędzy teorią najbliższego kontynuatora a zasadą autowłasności.

Metodą badawczą zastosowaną w analizie przedmiotowego problemu jest metoda równowagi refleksyjnej badająca koherencję zespołów twierdzeń, w szczególności koherencję zachodzącą pomiędzy teoriami tła, zasadami praktycznymi i intuicjami moralnymi, ontologicznymi i innymít. W niniejszym artykule analizowana jest za jej pomocą relacja pomiędzy libertariańską zasadą autowłasności (zasadą praktyczną) w jej czterech możliwych interpretacjach: szerokiej, wąskiej, silnej i słabej, która obok zasady nieagresji stanowi podstawę filozofii politycznej libertarianizmu, a teorią osoby/tożsamości sformułowaną przez Roberta Nozicka (teorią tła), która z tej właśnie racji, że zaproponowana została przez jednego z najważniejszych myślicieli libertariańskich, w sposób naturalny narzuca się jako możliwa antropologia filozoficzna libertarianizmu.

\section{TEORIA NAJBLIŻSZEGO KONTYNUATORA}

Teoria najbliższego kontynuatora została przedstawiona przez Nozicka w pierwszym rozdziale jego książki Philosophical Explanations. Zgodnie z teorią najbliższego kontynuatora "y” w czasie t2 jest ta sama osoba, co „x" w czasie t1 wtedy i tylko wtedy, gdy, po pierwsze, cechy posiadane przez "y" w czasie t2 wynikaja i sa przyczynowo zależne od cech „x" $w$ czasie t1 oraz, po drugie, nie istnieje żadne „z" $w$ czasie t2, które znajduje się $w$ blizszej relacji do " $x$ " $w$ czasie t 1 niz „y" $w$ czasie $t 2^{5}$. Teoria ta stanowi oczywiście próbę rozwiązania znanych paradoksów tożsamości osobowej w czasie. Aby zilustrować jej zastosowanie, przyjrzyjmy się krótko jednemu z takich paradoksów. W tym celu przeprowadźmy dwa znane w literaturze przedmiotu eksperymenty myślowe.

\section{Przeszczep ciała}

Załóżmy, że wraz ze swoim bratem bliźniakiem uczestniczyłeś w bardzo poważnym wypadku drogowym. W jego wyniku mózg twojego brata uległ całkowitemu zniszczeniu,

4 O metodzie równowagi refleksyjnej zob. N. Daniels, Wide Reflective Equilibrium and Theory Acceptance in Ethics, „The Journal of Philosophy” 1979, Vol. 76, nr 5, [online] http://dx.doi. org/10.2307/2025881; D.W. Haslett, What Is Wrong with Reflective Equilibria?, „The Philosophical Quarterly" 1987, Vol. 37, nr 148, [online] http://dx.doi.org/10.2307/2220400; J. Rawls, Outline of a Decision Procedure for Ethics, „The Philosophical Review” 1951, Vol. 60, nr 2, [online] http://dx.doi. org/10.2307/2181696; tenże, A Theory of Justice, Cambridge 1971; J.D. Arras, The Way We Reason Now: Reflective Equilibrium in Bioethics, [w:] The Oxford Handbook of Bioethics, red. B. Steinbock, New York 2007; N. Daniels, Reflective Equilibrium, [w:] The Stanford Encyclopedia of Philosophy, wiosna 2011, [online] https://plato.stanford.edu/archives/spr2011/entries/reflective-equilibrium/; R. Dworkin, Taking Rights Seriously, London 2013, Bloomsbury Revelations; E. Dominiak, Metoda równowagi refleksyjnej (reflective equilibrium) w filozofii polityki, „Athenaeum. Polskie Studia Politologiczne" 2012, Vol. 36.

5 R. Nozick, Philosophical Explanations, Cambridge 1981, s. 36-37. 
mimo że jego ciało pozostało nienaruszone, ty zaś doznałeś na tyle poważnego urazu wielonarządowego, że choć twój mózg jest nieuszkodzony, to umrzesz w ciągu kilku godzin. Jedyną szansą dla ciebie jest przeszczep całego ciała. Zaniepokojony perspektywą tak rewolucyjnej operacji, pytasz neurochirurga, co się z tobą stanie, kiedy ciało twojego brata zostanie przeszczepione na miejsce twojego obecnego, niefunkcjonującego ciała. Lekarz odpowiada, że będziesz pamiętał, czuł, zachowywał się i myślał dokładnie tak samo jak przed operacją i że procedura, która cię czeka, to tylko skrajny przypadek przeszczepu narządów; zamiast przeszczepu jednego organu zostanie wykonany przeszczep całego ciała, w wyniku którego ciało twojego brata bliźniaka znajdującego się w stanie śmierci mózgowej uratuje twoje życie. Czy ty przed operacją i po niej będziesz tą samą osobą?

Nasza intuicja mówi nam, że tak. W wyniku operacji nie zostaną naruszone nasze życie psychiczne, nasze wspomnienia, samoświadomość, charakter ani sposób zachowania. Po prostu obudzimy się z zestawem nowych organów, ale to nadal będziemy my. Ta silna intuicja ontologiczna może być i jest wyjaśniana za pomocą różnych teorii tożsamości. Dla celów dyskusji przyjmijmy, że najlepszym jej wyjaśnieniem jest psychologiczna teoria tożsamości wywodząca się od Johna Locke’a, a współcześnie reprezentowana przez Sydneya Shoemakera czy bardziej krytycznie przez Dereka Parfita. Zgodnie $\mathrm{z}$ tą teorią tożsamość osobowa w czasie polega na ciągłości psychologicznej, czyli opartej na związku przyczynowo-skutkowym ciągłości pamięci, zainteresowań, upodobań, talentów, cech osobowości i charakteru. Analitycznie rzecz ujmując: $y$ w czasie t2 i $x$ w czasie t 1 są jedną i tą samą osobą, jeśli $y$ jest ciągły psychologicznie z $x$ (ta definicja tożsamości osobowej nie wyznacza jej warunków wystarczających) ${ }^{7}$. Nazwijmy ten rodzaj związku, który decyduje, że $x$ w czasie t 1 i $y$ w czasie t2 są tą samą osobą, relacją R. Przejdźmy zatem do drugiego eksperymentu myślowego.

\section{Hemisferektomia}

Załóżmy, że w czasie twojego pobytu w szpitalu związanego z wypadkiem drogowym (tym razem doznałeś tylko relatywnie niegroźnych urazów), w którym uczestniczyłeś wraz ze swoim bratem bliźniakiem, poddano cię bardzo szczegółowym badaniom neurologicznym. W ich wyniku okazało się, że jesteś niezwykle rzadko spotykanym przypadkiem osoby, u której nie nastąpiła lateralizacja funkcji mózgu. Każda z obu półkul twojego mózgu jest w stanie kierować wszystkimi procesami i czynnościami niezależnie od drugiej półkuli; w każdej z nich z osobna znajduje się także pełna pamięć twojego przeszłego życia. Szalony neurochirurg postanawia wykorzystać tę sytuację, aby dokonać wiekopomnego wkładu w rozwój nauki, a jednocześnie uratować twojego brata bliźniaka, którego mózg uległ zniszczeniu w wyniku wypadku i który znajduje się w stanie śmierci mózgowej. Przeszczepia on twoją prawą półkulę mózgową do ciała twojego brata, „tobie” zostawiając półkulę lewą. Operacja się udaje. Co to dla ciebie oznacza?

6 S. Shoemaker, R. Swinburne, Personal Identity, Oxford 1984, s. 89-90, Great Debates in Philosophy.

Zob. D. Parfit, Reasons..., s. 207. 
Bez wątpienia pomiędzy tobą przed operacją ( $x \mathrm{w}$ czasie t1) i tobą - to znaczy twoim ciałem z lewą półkulą mózgową - po operacji ( $y$ w czasie t2) zachodzi relacja $\mathrm{R}$, a więc skłonni bylibyśmy dojść do konkluzji, że ty przed operacją ( $x$ w czasie t1) i ty po operacji ( $y$ w czasie $\mathrm{t} 2)$ to ta sama osoba.

$\mathrm{Z}$ drugiej jednak strony nie ma też wątpliwości, że pomiędzy tobą przed operacją ( $x \mathrm{w}$ czasie t1) a twoim bratem bliźniakiem - to znaczy ciałem twojego brata bliźniaka z twoją prawą półkulą mózgową - po operacji $(z$ w czasie t2) także zachodzi relacja $\mathrm{R}$, a więc i w tym przypadku bylibyśmy skłonni dojść do wniosku, że ty przed operacją ( $x$ w czasie $\mathrm{t} 1)$ i twój brat bliźniak po operacji $(z$ w czasie t2) to ta sama osoba. (Aby uniknąć błędnego koła w rozumowaniu należy traktować określenia typu „ty”, „twój brat bliźniak”, „ty po operacji” jako ilustrację problemu logicznego wyrażonego za pomocą zmiennych $x, y, z$ oraz $\mathrm{t} 1, \mathrm{t} 2$ ). Taka konkluzja rodzi jednak następujący paradoks.

Relacja tożsamości jest relacją przechodnią. Jeśli A jest tożsame z B, a B jest tożsame $\mathrm{z} \mathrm{C}$, to $\mathrm{A}$ jest tożsame $\mathrm{z}$ C. Zatem jeśli $x$ jest tożsame $\mathrm{z} y$ oraz jeśli $x$ jest tożsame $\mathrm{z} z$, to $y$ musi być tożsame $\mathrm{z} z$. Tak jednak nie jest: $y \mathrm{i} z$ nie są numerycznie identyczne; istnieją one symultanicznie (oba w czasie t2), a więc numerycznie wyróżniane są jako dwa obiekty, a nie jeden tożsamy ze sobą obiekt. Jakie są więc możliwe rozwiązania tego paradoksu? Ponieważ nie jest możliwe, aby $x$ było identyczne zarówno $z y$, jak i z $z$, pozostają tylko dwie możliwości: jest ono tożsame tylko z jednym z nich albo nie jest tożsame z żadnym z nich. Niestety, żadna z tych możliwości nie rozwiązuje paradoksu. Jeśli $x$ miałoby być tożsame tylko $\mathrm{z}$ jednym z obiektów, $y$ bądź $z$, naruszałoby to kryterium tożsamości i raziło całkowitą arbitralnością. Ponieważ relacja pomiędzy $x$ a $y$ jest identyczna $\mathrm{z}$ relacją pomiędzy $x \mathrm{a} z$ (w obu przypadkach jest to relacja $\mathrm{R}$ ), nie ma żadnych logicznych podstaw do dokonania wyboru pomiędzy nimi. Jeśli z kolei $x$ miałoby nie być tożsame z żadnym $z$ wynikłych obiektów $y \mathrm{i} z$, to wówczas poza naruszeniem kryterium tożsamości (pamiętajmy, że relacja $\mathrm{R}$ wiąże $x$ z oboma wynikłymi obiektami $y$ i $z$ ) oznaczałoby to, że operacja neurochirurgiczna wiązała się z twoją śmiercią (śmiercią $x$ ) i narodzinami dwóch nowych osób $(y$ i $z)$.

W związku z tym i podobnymi paradoksami teorii tożsamości osobowej Nozick zaproponował nowe kryterium tożsamości, które - jego zdaniem - pozwala uniknąć powyższych problemów. Zgodnie z tym kryterium, analitycznie przywołanym na początku tego paragrafu, relacja $R$ jest jedynie warunkiem koniecznym, ale niewystarczającym istnienia tożsamości osobowej. Oprócz relacji $\mathrm{R}$ musi zachodzić także relacja najbliższej kontynuacji, polegająca na tym, że nie istnieje żadne „z” w czasie t2, które znajduje się $w$ bliższej relacji do „x" $w$ czasie $t 1$ niz „y" $w$ czasie t2. Nie oznacza to, że w ogóle nie może istnieć żadne $z$, które pozostawałoby w relacji $\mathrm{R}$ do $x$, ale że relacja ta nie może być bliższa niż relacja pomiędzy $x$ a $y$, jeśli to $y$, a nie $z$ ma być tożsame $\mathrm{z} x$.

Teoria najbliższego kontynuatora Roberta Nozicka ma bez wątpienia dużo zalet. Przede wszystkim nie jest tak ściśle związana z żadną konkretną wersją redukcjonistycznej teorii tożsamości, ani psychologiczną, ani biologiczną. Pozwala np. definiować tożsamość osobową za pomocą kategorii psychologicznych, ale w sytuacji paradoksalnej odnieść się do innych kryteriów, jeśli cechy posiadane przez, ,y" w czasie t2 wynikają i sa przyczynowo zależne od cech „x" w czasie t1. W przypadku naszego paradoksu najbliższym kontynuatorem 
$x$ jest $y$, ponieważ poza psychologiczną relacją $\mathrm{R} y$ jest biologicznie bliższym kontynuatorem $x$ niż, też pozostający w psychologicznej relacji $\mathrm{R}$ do $x, z$. Jak zauważa sam Nozick, $w y$ daje się, że bliższym kontynuatorem jest osoba posiadająca oryginalne ciato plus pótkulę mózgu, która jej pozostata. Obie wynikte osoby sa w petni psychologicznie ciagte z osoba wyjściowa, obie sq także w pewnym stopniu ciagte cieleśnie, jakkolwiek w jednym przypadku jest to tylko pótkula mózgu [...].Jedna osoba posiada zatem większa zbieżnośćfizyczną .

Teoria najbliższego kontynuatora rozwiązuje więc część paradoksów tożsamości osobowej, jednak sama także nie unika sobie właściwych problemów. Ponieważ celem tego artykułu nie jest ocena spójności teorii najbliższego kontynuatora, lecz jej możliwa zgodność z zasadą autowłasności, w tym miejscu zwrócimy uwagę tylko na dwa główne problemy teorii Nozicka. Po pierwsze, teoria ta stanowi naruszenie postulatu Bernarda Williamsa, zgodnie z którym coś tak istotnego jak tożsamość osobowa nie może być kwestią faktów o zupełnie marginalnym znaczeniu'. Na przykład tak fundamentalne pytanie, czy po operacji przeszczepu mojej jednej półkuli mózgu do ciała mojego brata bliźniaka nadal będę sobą, czy będzie mną mój brat bliźniak, nie może zależeć od kwestii tak nieistotnej jak to, czy będę miał o jeden neuron więcej czy mniej niż mój brat bliźniak. Po drugie, co wiąże się ściśle z pierwszym problemem, teoria Nozicka uzależnia kwestię tożsamości danej osoby w czasie nie od faktów dotyczących tej osoby (np. od tego, czy dana osoba wczoraj i dana osoba dzisiaj posiada te same wspomnienia, oczekiwania, pragnienia, cechy charakteru etc., krótko mówiąc, czy łączy je relacja R), ale od okoliczności zupełnie od tej osoby niezależnych (np. to, czy neurochirurg po hemisferektomii zutylizuje wyciętą półkulę, czy wszczepi ją do innego ciała).

Oba te problemy teorii Nozicka są bardzo poważne i rodzą kolejne paradoksy, podając w ten sposób całą teorię najbliższego kontynuatora w wątpliwość. W tym miejscu nie interesuje nas jednak pytanie, czy teoria ta jest w stanie poradzić sobie ze wszystkimi bądź z większością dotykających ją problemów (jakkolwiek uważamy, że nie jest w tym aspekcie "gorsza” od innych redukcjonistycznych teorii tożsamości osobowej), ale czy może stanowić teorię tła dla libertariańskiej zasady autowłasności. W tym celu przeanalizujemy teraz główne twierdzenia konstytuujące libertariańską zasadę autowłasności.

\section{ZASADA AUTOWŁASNOŚCI}

Zasada autowłasności jest obok zasady nieagresji głównym fundamentem teoretycznym filozofii politycznej libertarianizmu. W swej najbardziej podstawowej wersji głosi ona, że każdy człowiek jest, oryginalnie, autowłaścicielem. Sformułowanie to, choć intuicyjnie oczywiste, jest jednak w istocie dalece wieloznaczne i aby możliwe było zastosowanie zasady autowłasności do konstruowania filozofii politycznej libertarianizmu, wymaga ono analitycznego wyjaśnienia. Naszym zdaniem można wskazać dwa główne, z punktu widzenia naszych celów, kryteria interpretacyjne zasady autowłasności: 1) pod względem

8 R. Nozick, Philosophical Explanations, s. 40.

9 B. Williams, Problems of the Self. Philosophical Papers, 1956-1972, Cambridge 1973, s. 21. 
zakresu praw własności; 2) pod względem siły praw własności. Przez pojęcie zakresu praw własności rozumiemy zbiór obiektów, do których jednostka ma prawa własności; im większy zbiór, tym większy zakres praw własności. Natomiast przez pojęcie siły praw własności rozumiemy stopień kontroli jednostki nad posiadanymi obiektami; im większa kontrola, tym większa siła praw własności. W literaturze przedmiotu wyróżnia się zasadniczo jedenaście incydentów konstytuujących prawo własności, spośród których prawo do posiadania jest fundamentem, na którym opiera się cata nadbudowa wtasności $\left.i^{10}: 1\right)$ prawo do posiadania (right to possess); 2) prawo do używania danej rzeczy (right to use); 3) prawo do zarządzania daną rzeczą (right to manage); 4) prawo do czerpania dochodu (right to the income); 5) prawo do kapitału (right to the capital); 6) prawo do bezpieczeństwa (right to security); 7) incydent przekazywalności (incident of transmissibility); 8) incydent braku ograniczenia czasowego (incident of the absence of term); 9) zakaz szkodliwego użycia (probibition of harmful use);10) podatność na egzekucję (liability to execution); 11) prawo rezydualne do rzeczy będącej przedmiotem własności (residuary right $)^{11}$.

Libertarianizm nie jest zgodny co do interpretacji zasady autowłasności ${ }^{12}$. Analiza literatury prymarnej pozwala wyodrębnić kilka różnych ujęć tej zasady. Według

10 A.M. Honoré, Ownership, [w:] Oxford Essays in Jurisprudence (First Series), red. A.G. Guest, Oxford 1961, s. 113; R.S. Taylor, Self-Ownership and the Limits of Libertarianism, „Social Theory and Practice" 2005, Vol. 31, nr 4, s. 371, [online] http://dx.doi.org/10.5840/soctheorpract200531423.

11 A.M. Honoré, Ownership, s. 372-375.

12 Zob. m.in.: R.J. Arneson, Property Rights in Persons, „Social Philosophy and Policy” 1992, Vol. 9 , nr 1, s. 201-230, [online] http://dx.doi.org/10.1017/S0265052500003654; tenże, Self Ownership and World Ownership: Against Left-Libertarianism, „Social Philosophy and Policy” 2010, Vol. 27, nr 1, s. 168-194, [online] http://dx.doi.org/10.1017/S0265052509990070; tenże, Lockean Self-Ownership: Towards a Demolition, „Political Studies” 1991, Vol. 39, nr 1, s. 36-54, [online] http:// dx.doi.org/10.1111/j.1467-9248.1991.tb00580.x; B. Barry, Self Ownership and the Libertarian Challenge, „Times Literary Supplement” 1996, 15 XI, s. 19; G.A. Cohen, Self-Ownership, Freedom, and Equality, Cambridge 1995, Studies in Marxism and Social Theory; M. Dan-Cohen, Responsibility and the Boundaries of the Self, "Harvard Law Review” 1992, Vol. 105, nr 5, s. 959-1003; tenże, The Value of Ownership, „The Journal of Political Philosophy” 2001, Vol. 9, nr 4, s. 404-434; E. Feser, Self-Ownership, Abortion, and the Rights of Children: Toward a More Conservative Libertarianism, "The Journal of Libertarian Studies" 2004, Vol. 18, nr 3, s. 91-114; M. Gorr, Justice, Self-Ownership, and Natural Assets, „Social Philosophy and Policy” 1995, Vol. 12, nr 2, s. 267-291, [online] http://dx. doi.org/10.1017/S0265052500004751; K. Lippert-Rasmussen, Against Self-Ownership: There Are No Fact-Insensitive Ownership Rights over One's Body, „Philosophy and Public Affairs” 2008, Vol. 36, nr 1, s. 86-118, [online] http://dx.doi.org/10.1111/j.1088-4963.2008.00125.x; E. Mack, The Self-Ownership Proviso: A New and Improved Lockean Proviso, "Social Philosophy and Policy” 1995, Vol. 12, nr 1, s. 186-218; T.G. Palmer, G.A. Cohen on Self-Ownership, Property, and Equality, "Critical Review. A Journal of Politics and Society" 1998, Vol. 12, nr 3, s. 225-251, [online] http://dx.doi. org/10.1080/08913819808443498; C. Pateman, Self-Ownership and Property in the Person: Democratization and a Tale of Two Concepts, „The Journal of Political Philosophy” 2002, Vol. 10, nr 1, s. 22 -53, [online] http://dx.doi.org/10.1111/1467-9760.00141; M. Pendlebury, P. Hudson, D. Moellendorf, Capitalist Exploitation, Self-Ownership, and Equality, „The Philosophical Forum” 2001, Vol. 32, nr 3, s. 207-220, [online] http://dx.doi.org/10.1111/0031-806X.00062; A. Ryan, Self-Ownership, Autonomy, and Property Rights, „Social Philosophy and Policy” 1994, Vol. 11, nr 2, s. 241-258, [online] http://dx.doi.org/10.1017/S0265052500004507; J. Weinberg, Freedom, Self-Ownership, and Libertarian Philosophical Diaspora, "Critical Review. A Journal of Politics and Society” 1997, Vol. 11, nr 3, s. 323-344, [online] http://dx.doi.org/10.1080/08913819708443464. 
kryterium zakresu praw własności można mówić o szerokiej i wąskiej zasadzie autowłasności. W pierwszym, szerokim sensie zasada autowłasności mówi, że człowiek jest właścicielem zarówno swego ciała, jak i umysłu. Interpretacja ta wywodzi się bezpośrednio od teorii własności Johna Locke’a, który w słynnym fragmencie Dwóch traktatów o rządzie stwierdzit, że każdy cztowiek dysponuje własnością swej osoby. Nikt nie ma do niej żadnego uprawnienia poza nim samym. Możemy więc powiedzieć, że praca jego ciata $i$ dzieło jego rąk stusznie należa do niego [...] Praca ta jest bezsprzecznie wtasnościa pracownika ${ }^{13}$. Oznacza to, że teoria Locke’a dopuszcza (auto)własność „,rzeczy” niematerialnych, takich jak fakty mentalne czy określone działania. Locke rozumiał osobę w kategoriach psychologicznych jako ciągłość świadomości (pamięci), nie zaś jako rzecz materialną (lub niematerialną substancję). W Rozważaniach dotyczacych rozumu ludzkiego mówi on wyraźnie o tym, że mamy do czynienia z tą samą osobą tak długo, jak dalece rozciąga się jej świadomość (pamięć), nawet jeśli miałaby ona być realizowana w kolejnych ciałach ${ }^{14}$. Podobnież dopuszczenie przez Locke’a możliwości bycia właścicielem pracy sugeruje, że niematerialne obiekty mogą być przedmiotem własności, praca bowiem jest rodzajem działania, a nie dobrem materialnym ${ }^{15}$.

Śladem tej interpretacji Locke’a podążają tacy libertarianie, jak inter alia Murray Rothbard czy Edward Feser. Afiliację tę potwierdzają liczne twierdzenia myślicieli libertariańskich wskazujące na możliwość bycia właścicielem faktów mentalnych, działań, umysłu, świadomości czy, ogólnie rzecz biorąc, obiektów niematerialnych. Można w tym miejscu przywołać takie sformułowania, jak: każda jednostka w petni posiada i ma petne prawa wtasności do siebie samej - do swojego ciata i jego czéści, do swoich talentów izdolności, do swojej pracy oraz sit fizycznych i psychicznych ${ }^{16}$; każdy cztowiek jest wtaścicielem swojego umystu i ma prawo wtasności do swoich przekonañ ${ }^{17}$; każdy cztowiek jest wtaścicielem swojej wtasnej osoby ${ }^{18}$, ego każdego cztowieka jest wtaścicielem jego osoby ${ }^{19}$ albo na mocy aksjomatu autowtasności każda jednostka ma absolutne prawo do swojego umystu i ciata oraz jego pracy, tj. każda osoba ma prawo do sprawowania kontroli nad tym umystem i ciatem bez ingerencji i przymusu ze strony innych. Nazwijmy tę interpretację szeroką zasadą autowłasności.

Można jednak interpretować zasadę autowłasności także w węższy sposób. Zgodnie z tym wąskim sposobem interpretacji zasada autowłasności stanowi, że człowiek jest właścicielem swojego ciała, ale nie umysłu. Uzasadnieniem tej wąskiej interpretacji zasady autowłasności jest teoria praw własności rozwijana głównie przez Hansa-Hermanna

13 J. Locke, Dwa traktaty o rządzie, przeł. Z. Rau, Warszawa 1992, §27, s. 181-182, Biblioteka Klasyków Filozofii.

14 Zob. tenże, Rozważania dotyczace rozumu ludzkiego, t. 2, przeł. B.J. Gawecki, Warszawa 1955, rozdz. 27: O tożsamości i różnicy.

15 S. Kinsella, Against Intellectual Property, Auburn 2008, s. 38.

16 E. Feser, Personal Identity and Self-Ownership, „Social Philosophy and Policy” 2005, Vol. 22, nr 2, s. 101.

17 M. Rothbard, The Ethics of Liberty, New York 1998, s. 126.

18 Tenże, For a New Liberty. The Libertarian Manifesto, Auburn 2002, s. 33.

19 Tenże, The Ethics..., s. 41. 
Hoppego i Stephana Kinsellę, zgodnie z którą prakseologicznym warunkiem możliwości istnienia praw własności jest rzadkość dóbr; prawa własności służą bowiem rozwiązywaniu konfliktów o dobra rzadkie i w związku z tym mogą dotyczyć tylko takich dóbr. Uznanie rzadkości dóbr jest punktem wyjścia filozofii politycznej [...]. Gdyby dobra występowaty w nieograniczonych ilościach [...], problemy etyczne dotyczace uprawnieńn i ich naruszeń, sprawiedliwości i niesprawiedliwości w ogóle by się nie pojawity, ponieważ niemożliwe jest powstanie konfliktu co do użycia takich dóbr ${ }^{20}$. Obiekty mentalne, takie jak: wspomnienia, upodobania, zainteresowania, wiedza, idee, pomysły, teorie etc., nie są same w sobie dobrami rzadkimi. Idee - receptury, formuty, twierdzenia, argumenty, algorytmy, teorematy, melodie, wzorce, rytmy, obrazy etc. - z pewnościa sq dobrami, ale nie sa dobrami rzadkimi. Kiedy zostają pomyślane i wyrażone, stają się dobrami wolnymi i niewyczerpalnymi ${ }^{21}$. Jeśli ty formułujesz jakąś myśl, którą ja następnie ci „zabieram”, „kradnę”, „przywłaszczam”, nadal masz swoją myśl, nie straciłeś jej; to, co ulega zmianie, to fakt, że odtąd także ja mam tę myśl. Jeśli natomiast posiadasz samochód, który ja „zabieram”, „kradnę”, „przywłaszczam”, ty nie masz już samochodu, straciłé go; mam go tylko ja. Taka, najprościej rzecz ujmując, jest różnica pomiędzy dobrami niewyczerpalnymi a rzadkimi. Idee nie sq rzadkie [...]. W ich przypadku nie ma miejsca ekonomiczna rzadkość, a zatem nie występuje także możliwość powstania konfliktu o rzadkie zasoby. A zatem nie ma podstawy do ochrony ich wytaczności $i^{22}$. Fakty mentalne mogą być dobrami rzadkimi tylko w sensie wtórnym - jako mające swą fizyczną realizację, która to realizacja (mózg, głowa, struny głosowe etc.) ze względu na swą rzadkość jest jedynym możliwym i pierwotnym przedmiotem praw własności. Aby w ogóle mieć jakaśs myśl, musisz mieć prawo wtasności do swojego ciata. Nie oznacza to, że posiadasz swoje myśli. Twoje myśli moga być bowiem użyte przez każdego, kto je rozumie $e^{23}$.

Interpretacja ta wyraża się w takich stwierdzeniach, jak: osiaganie praw do samoposiadania może być postrzegane jako rodzaj pierwotnego przywtaszczenia swojego ciata ${ }^{24}$; ciato cztowieka jest w istocie prototypem dobra rzadkiego, dla którego uzycia prawa wtasności, tj. prawa wytacznego posiadania, musza być ustanowione $w$ celu uniknięcia konfliktów ${ }^{25}$; autowtasność to ściślej rzecz ujmując wtasność ciata ${ }^{26}$. Nazwijmy tę interpretację wąską zasadą autowłasności.

20 H.-H. Hoppe, The Economics and Ethics of Private Property. Studies in Political Economy and Philosophy, Auburn 2006, s. 333.

21 Tenże, The Great Fiction. Property, Economics, Society, and the Politics of Decline, Baltimore 2012, s. 397.

22 S. Kinsella, Against..., s. 32.

23 H.-H. Hoppe, The Praxeological Foundations of Epistemology and Ethics, Q\&A, „Austrian Economics Newsletter" 1988, Vol. 9, nr 2, s. 7.

24 S. Kinsella, How We Come to Own Ourselves, „Mises Daily” 2006, 7 IX, [online] http://mises.org/library/how-we-come-own-ourselves, 14 III 2015.

25 H.-H. Hoppe, A Theory of Socialism and Capitalism. Economics, Politics, and Ethics, Auburn 2012, s. 19, Ludwig von Mises Institute's Studies in Austrian Economics.

26 A. Wile, Stephan Kinsella, Oon Libertarian Legal Theory, Self-Ownership, and Drug Laws. Exclusive Interview, „The Daily Bell” 2014, 20 VII, [online] http://www.thedailybell.com/ 
Według kryterium siły praw własności można mówić o pełnej i ograniczonej autowłasności. W pierwszym sensie jednostka miałaby względem siebie samej (nie rozstrzygając jeszcze, co to znaczy „siebie samej”) wszystkie jedenaście Honoréowskich incydentów własności. W szczególności miałaby ona prawo zbywalności praw własności do siebie samej, wyrażające się np. w możliwości istnienia instytucji dobrowolnego niewolnictwa. Tego typu interpretację zasady autowłasności reprezentują Robert Nozick i Walter Block, a poniekąd także Hillel Steiner. Zgodnie ze stanowiskiem Nozicka $c z t o-$ wiek może podjać decyzje o zrobieniu sobie (lub pozwoleniu komuś innemu na zrobienie sobie) wszystkiego, pod warunkiem że nie zobowiazat się osobom trzecim, że tego nie zrobi badź nie pozwoli na to innym ${ }^{27}$. Z kolei Block broni filozofii libertariańskiej, zgodnie $z$ która wszystko powinno być legalnie zbywalne ${ }^{28}$. Natomiast dla Steinera dobrowolne niewolnictwo mogłoby mieć miejsce przypuszczalnie tylko $w$ drodze porzucenia prawa autowtasności; to znaczy, nie mogtoby ono być wynikiem transferu (sprzedaży badź darowania) tego prawa, poniewaz wiazatoby się to $z$ powstaniem po stronie transferujacego obowiązku względem osoby, do której następowatby taki transfer, a wiemy, że niewolnicy, będą rzeczami znajdującymi się we wtasności innych, z konieczności nie maja ani obowiązków, ani praw ${ }^{29}$. Nazwijmy tę interpretację silną zasadą autowłasności.

W drugim ujęciu zasady autowłasności jednostka nie posiadałaby względem siebie samej wszystkich jedenastu incydentów własności. W szczególności nie miałaby ona prawa wyzbycia się praw własności do siebie samej, co wyrażałoby się w niemożliwości istnienia instytucji dobrowolnego niewolnictwa. Tego typu interpretację zasady autowłasności reprezentują de facto wszyscy czołowi libertarianie poza Nozickiem, Blockiem i Steinerem, w szczególności zaś Rothbard i Hoppe. Tak więc Rothbard twierdzi, że żadna osoba nie może zbyć swojej woli, w szczególności swojej kontroli nad własnym umysłem i ciałem, [...] stąd na gruncie filozofii libertarianskiej umowy o dobrowolne niewolnictwo sa niemożliwe do zrealizowani $a^{30}$. Natomiast Hoppe uważa, że tego typu umowy są w ramach porządku libertariańskiego niedozwolone (a więc nieważne), ponieważ sa sprzeczne $z$ prakseologiczna podstawa wszelkich umów, tj. z wtasnościa prywatnq i indywidualnq autowtasnością ${ }^{31}$. Nazwijmy tę interpretację słabą zasadą autowłasności.

W następnym paragrafie wrócimy do tych interpretacji zasady autowłasności w kontekście interesującego nas pytania o teorię osoby. W tym miejscu natomiast chcemy jeszcze określić specyficzny status poznawczy zasady autowłasności, który determinuje zarówno nasze główne pytanie badawcze, jak i znaczenie udzielonej odpowiedzi dla filozofii politycznej libertarianizmu.

exclusive-interviews/35492/Anthony-Wile-Stephan-Kinsella-on-Libertarian-Legal-Theory-Self-Ownership-and-Drug-Laws/, 14 III 2015.

27 R. Nozick, Anarchy, State, and Utopia, Oxford 1999, s. 58.

W. Block, Toward a Libertarian Theory of Inalienability: A Critique of Rothbard, Barnett, Smith, Kinsella, Gordon, and Epstein, „The Journal of Libertarian Studies” 2003, Vol. 17, nr 2, s. 41.

M. Rothbard, The Ethics..., s. 135.

31 H.-H. Hoppe, Democracy - The God That Failed. The Economics and Politics of Monarchy, Democracy, and Natural Order, New Brunswick 2007, s. 227. 
W przeciwieństwie do standardowej sytuacji wypracowywania równowagi refleksyjnej pomiędzy zespołami twierdzeń, gdzie poszczególne twierdzenia modyfikowane są w celu osiągnięcia koherencji i żadne z nich nie jest traktowane jako niewzruszone, libertariańska zasada autowłasności ma status aksjomatu i nie podlega zmianie w procesie dążenia do równowagi refleksyjnej ${ }^{32}$. Aksjomatyczność jest tu rozumiana za Arystotelesem jako sytuacja, w której 1) dowodzenie danego twierdzenia jest niemożliwe bez popadania w błąd petitio principii, ponieważ twierdzenie to stanowi podstawę wszelkiego dowodzenia; 2) zaprzeczenie danego twierdzenia także jest niemożliwe bez popadania w błąd petitio principii, ponieważ samo zakłada jako swoją podstawę twierdzenie, któremu przeczy (elenchos) ${ }^{33}$.

Aksjomatyczny charakter zasady autowłasności został najprecyzyjniej wykazany przez Hansa-Hermanna Hoppego za pomocą jego koncepcji a priori argumentacyjnego $^{34}$. Rozumowanie to można sparafrazować inter alia w następujący sposób. Jeśli ktoś chciałby argumentować, że człowiek nie jest autowłaścicielem, to samym faktem sformułowania tego argumentu nolens volens dowodziłby, że ma prawo własności do samego siebie, do swojego ciała, do swojego mózgu i strun głosowych (oraz innych jego części) i właśnie korzysta z tego prawa w celu sformułowania, zgodnie z własną wolą, tego oto argumentu, popadając tym samym w niespójność performatywną ${ }^{35}$ (poniższy przypis odnosi do pełnej i niesparafrazowanej argumentacji demonstrującej aksjomatyczny charakter zasady autowłasności). W zależności od tego, czy argumentacja ta byłaby skierowana przeciwko wąskiej czy szerokiej zasadzie autowłasności, niespójność performatywna byłaby odpowiednio rozumiana w sposób wąski bądź szeroki, czyli jako dotycząca tylko praw własności do ciała bądź także do myśli czy, ogólnie rzecz ujmując, faktów mentalnych.

Aksjomatyczność zasady autowłasności determinuje rodzaj pytania badawczego, które może zadać niniejszy artykuł, oraz znaczenie udzielonej odpowiedzi dla filozofii politycznej libertarianizmu. Ponieważ zasada autowłasności jest twierdzeniem oczywistym i niedowodliwym, pytanie „czy możliwa jest zasada autowłasności?” jest,

32 Jest to ciekawy przypadek w kontekście ogólnych rozważań metodologicznych nad metodą równowagi refleksyjnej, który wedle mojej najlepszej wiedzy nie został dotąd jeszcze przez nikogo zauważony. Ronald Dworkin w pracy Biorac prawa poważnie zwrócił uwagę na dwa możliwe warianty metody równowagi refleksyjnej ze względu na konstruktywistyczny bądź naturalistyczny model rozumienia intuicji. W ramach modelu naturalistycznego intuicje moralne czy ontologiczne traktowane są na zasadzie analogicznej do danych zmysłowych w naukach przyrodniczych, czyli jako ostateczny test zasad moralnych i teorii tła, nie podlegają przeto procesowi dostosowywania do pozostałych zespołów twierdzeń. Przypadek zasady autowłasności, jak i podobne przypadki podstawowych zasad prawa naturalnego wyróżnianych np. przez nową teorię prawa naturalnego Johna Finnisa i innych, jest przypadkiem, w którym to zasady moralne (przedmoralne) ze względu na swój aksjomatyczny charakter nie podlegają procesowi dostosowywania do pozostałych zespołów twierdzeń, lecz stanowią ich ostateczny test. Można w związku z tym, per analogiam z rozróżnieniem Dworkina, mówić o aksjomatycznym (niedowodliwym) i demonstratywnym (dowodliwym) modelu równowagi refleksyjnej.

33 Arystoteles, Metafizyka, przeł. K. Leśniak, Warszawa 2009, 1006a.

34 H.-H. Hoppe, Economic Science and the Austrian Method, Auburn 2012, s. 65-67.

35 Tenże, Democracy..., s. 200-202. 
parafrazując Immanuela Kanta, niepotrzebne i pozostaje jedynie pytanie, które dotyczy raczej wypróbowania naszej bystrości niż dowodu istnienia samej rzeczy, mianowicie: w jaki sposób jest ona możliwa? Odpowiedź na pytanie „jakiego rodzaju istotą musi być człowiek, skoro jest autowłaścicielem?” nie może więc zasadniczo podważyć samej zasady autowłasności ani nie może stanowić jej dowodu. Może mieć natomiast - i naszym zdaniem ma - istotne konsekwencje dla bardziej szczegółowych twierdzeń libertarianizmu, np. dotyczących problemów bioetycznych, nakładając ograniczenia na ich możliwe rozwiązania. $Z$ aksjomatu autowłasności wyprowadzane są za pomocą dedukcji inne twierdzenia libertarianizmu.

Ta funkcja zasady autowłasności nie jest jednak jedyna. Patrząc bowiem przez pryzmat zasady autowłasności w jednym kierunku, widzimy filozofię polityczną i moralną libertarianizmu, coraz bardziej szczegółowe twierdzenia wydedukowane z aksjomatu autowłasności; patrząc jednak w kierunku przeciwnym, widzimy antropologię filozoficzną libertarianizmu, która także musi być dedukowalna z aksjomatu autowłasności. Pytanie o to, któremu z tych zespołów twierdzeń - antropologicznemu czy filozoficzno-politycznemu - powinno się przypisywać większe znaczenie w rozwiązywaniu danych problemów szczegółowych, nie znajduje odpowiedzi w aksjomacie autowłasności (ponieważ oba zespoły twierdzeń są dedukowalne z tego aksjomatu), lecz jest przedmiotem badawczym, do którego zastosowanie ma metoda równowagi refleksyjnej.

\section{TEORIA NAJBLIŻSZEGO KONTYNUATORA A ZASADA AUTOWŁASNOŚCI}

Możemy w tym miejscu przejść do głównego problemu badawczego niniejszego artykułu: „Czy koncepcja najbliższego kontynuatora może być teorią tła zasady autowłasności?”. Pojęcie własności czy prawa do posiadania, w tym prawa do samoposiadania, zakłada rozróżnienie pomiędzy tym, kto posiada, a tym, co jest posiadane, oraz pomiędzy tym, kto jest właścicielem, a tym, co jest jego własnością. Aby posiadać daną rzecz, a więc także a fortiori, aby mieć prawo - na mocy zasady Sollen impliziert Können - do jej posiadania, nie mogę być tą rzeczą. Jeśli posiadam samochód, oznacza to nie tylko, że nie jestem tym samochodem, ale także że nie moge być tym samochodem tak długo, jak go posiadam. Kategoria tego, kim jestem, i kategoria tego, co posiadam (a więc i tego, co posiadam prawowicie), to, ujmując rzecz w terminach teorii mnogości, zbiory rozłączne. Jeśli jestem organizmem ludzkim, to z logicznego punktu widzenia nie posiadam organizmu - jakkolwiek mój zwyczajowy sposób wyrażania się może sugerować co innego (ale per analogiam mój zwyczaj językowy sugeruje też, że Słońce wstaje i zachodzi). Podobnież jeśli mam prawo własności do tego oto organizmu, to znaczy, że nie jestem tym oto organizmem. Gdybym w którymś momencie posiadł organizm lub stał się jego właścicielem, z definicji przestałbym być tym organizmem. Jeśli jestem umysłem bądź świadomością, wówczas nie posiadam umysłu ani świadomości, lecz istotowo nimi jestem. W takim wypadku pomiędzy mną a "moją” świadomością bądź umysłem zachodzi logiczna relacja tożsamości, nie zaś relacja posiadania czy prawa do 
posiadania. Jak zauważył Michael Sandel w kontekście liberalnej koncepcji jaźni: $w$ tej mierze, w jakiejposiadam jakąśrzecz, jestem jednocześnie zwiazany z ta rzeczą i oddzielony od niej. Powiedzieć, że posiadam określona cechę, pragnienie czy ambicję, to powiedzieć, $\dot{z}$ e jestem z nia zwiazany w określony sposób - że jest ona raczej moja niż twoja - a także $\dot{z} e$ jestem od niej oddzielony w określony sposób - że jest ona raczej moja, niż jest mnac. Ta druga kwestia oznacza, że jeśli stracę rzecz, która posiadam, wciąż jestem tym samym „ja”, które wcześniej rzecz tę posiadato [...]. Ten dystansujacy aspekt jest kluczowy dla ciagtości jaźni ${ }^{36}$.

Na czym polega ten określony sposób, w który jestem związany z rzeczą, jeśli ją posiadam, a także jeśli jest ona moją własnością? W pierwszym przypadku związek ten polega na mojej możliwości władania tą rzeczą dla siebie przy wykluczeniu działań innych osób ${ }^{37}$. Natomiast w tym drugim związek ten można z analitycznego punktu widzenia sprowadzić do incydentów własności, do praw kontroli wskazanych powyżej: 1) prawa do posiadania; 2) prawa do używania danej rzeczy; 3) prawa do zarządzania daną rzeczą; 4) prawa do czerpania dochodu; 5) prawa do kapitału; 6) prawa do bezpieczeństwa; 7) incydentu przekazywalności; 8) incydentu braku ograniczenia czasowego; 9) zakazu szkodliwego użycia; 10) podatności na egzekucję; 11) prawa rezydualnego. W tym sensie dana rzecz jest raczej moja niż twoja.

Na czym z kolei polega ów określony sposób, w który jestem oddzielony od rzeczy, którą odpowiednio posiadam bądź która jest moją własnością? W zależności od tego, czy mamy do czynienia z nieredukcjonistyczną czy też z redukcjonistyczną teorią osoby, sprowadza się on odpowiednio do tego, że żadna rzecz nie może konstytuować mojego ,ja”, ponieważ jest ono proste, niepodzielne i nie składa się z żadnych innych rzeczy (w zależności od wersji teorii osoby argument ten może jednak przybierać także inne formy), bądź że rzecz, którą posiadam lub która jest moją własnością, nie może być elementem relacji R, do której sprowadza się moja osoba i jej tożsamość.

Posiadanie danej rzeczy można utracić na dwa przeciwstawne sposoby. Stopniowo trace posiadanie danej rzeczy nie tylko wtedy, gdy oddala się ona od mojej osoby, ale także wtedy, gdy dystans pomiędzy moja jaźnia a tą rzecza zmniejsza się i zmierza ku catkowitemu zanikowi [...]. Pierwszy rodzaj utraty posiadania wiąże się z oddalaniem się obiektu od jaźni, do której obiekt ten swego czasu należat. W coraz większym stopniu staje się niejasne, w jakim sensie obiekt ten jest raczej mój, niż twój [...]. Drugi rodzaj utraty posiadania ostabia jaźń w inny sposób. Tutaj problem nie polega na przezwycięzaniu dystansu wytworzonego przez oddalenie się obiektu od jaźni, ale raczej na tego dystansu odbudowaniu i utrzymaniu [...] [ponieważ inaczej będę] niezdolny do rozróżnienia pomiędzy tym, co jest moje, a tym, co jest mna $q^{38}$.

Także w odniesieniu do własności można by analogicznie wskazać dwa sposoby utraty własności danej rzeczy przez osobę za pomocą wspomnianego wcześniej kryterium siły praw własności. Z pierwszym sposobem utraty własności mielibyśmy do

\footnotetext{
36 M. Sandel, Liberalism..., s. 55.

37 F.C. von Savigny, Das Recht des Besitzes. Eine civilistische Abhandlung, Wien 1865, s. 26.

38 M. Sandel, Liberalism..., s. 57-58.
} 
czynienia wtedy, gdy któreś z jedenastu praw kontroli (lub większa ich liczba) zostałoby utracone na rzecz innej osoby, wspólnoty, państwa bądź innego podmiotu. Jednym z wielu, powszechnych dzisiaj, przypadków utraty praw kontroli na rzecz państwa jest konstytucyjna możliwość wywłaszczenia na cele publiczne. $\mathrm{Z}$ drugim sposobem utraty własności mielibyśmy natomiast do czynienia wtedy, gdy któreś z praw własności zostałoby „utracone na rzecz samego właściciela” poprzez uznanie danej własności za niezbywalną, jak ma to miejsce choćby w przypadku prawnego zakazu handlu organami ludzkimi.

Pojęcie dystansu presuponowane przez relację posiadania oraz własności pozwala na ostateczną odpowiedź na nasze pytanie badawcze. Ogólna struktura logiczna naszej odpowiedzi wyglądałaby zatem następująco: aby teoria najbliższego kontynuatora mogła być teorią tła zasady autowłasności, wówczas to, kim według tej teorii jestem, nie mogłoby być tym, co według zasady autowłasności mogę objąć swoją własnością.

Teorie osoby/tożsamości osobowej w czasie można podzielić na dwa główne typy: teorie redukcjonistyczne i nieredukcjonistyczne. Te pierwsze przyjmują, że istniejepewna relacja (inna niż sama tożsamość) lub zbiór relacji, które musza zachodzić pomiędzy dana osoba we wcześniejszym czasie a dana osoba w późniejszym czasie, aby można byto powiedzieć, że osoby te sa jedna i ta sama osoba w różnych momentach. Z kolei teorie nieredukcjonistyczne głoszą, że tożsamość osobowa w czasie nie jest redukowalna ani wyjaśnialna w kategoriach żadnej innej rzeczy. Wielu ludzi np. wierzy, że w swej istocie jesteśmy niematerialna substancją lub dusza [...], która uważana jest za prosta i niepodzielna. Nie jest ona ztożona $z$ niczego innego, niż ona sama [...], a jej trwanie $w$ czasie nie może być analizowane w kategoriach jakichs' innych rzeczy czy relacji ${ }^{39}$, lecz to te rzeczy i relacje muszą być analizowane w kategoriach owej niematerialnej jaźni, duszy, substancji czy tożsamości.

Bez wątpienia teoria najbliższego kontynuatora Roberta Nozicka jest typem redukcjonistycznej teorii osoby/tożsamości. Jej nowatorstwo w stosunku do innych redukcjonistycznych teorii tożsamości polega tylko na tym, że do danej relacji R (czy to psychologicznej, czy cielesnej ciągłości) dodaje ona drugi warunek najbliższej kontynuacji. Sam Nozick w taki sposób klasyfikuje swoją teorię najbliższego kontynuatora, gdy mówi, że X jest tożsame z jakąś inną, wcześniejszą rzeczą, jeśli X stoi do tej innej, wcześniejszej rzeczy $w$ określonej relacji $R$ oraz że do tego relacyjnego pogladu dodany jest warunek, zgodnie z którym nic innego nie może być tak samo blisko związane relacja $R$ z tą wcześniejszą rzecz $q^{40}$. Czy teoria ta może w związku z tym być teorią tła zasady autowłasności?

W bardzo ważnym dla badań nad antropologią filozoficzną libertarianizmu artykule Personal Identity and Self-Ownership konserwatywny libertarianin Edward Feser odrzuca teorię najbliższego kontynuatora jako niekompatybilna z silnym pojęciem autowtasności (co jest wyjątkowo ironiczne, biorac pod uwage fakt, że Nozick, prawdopodobnie

39 J. McMahan, The Ethics of Killing. Problems at the Margins of Life, New York 2002, s. 5, Oxford Ethics Series.

40 R. Nozick, Philosophical Explanations, s. 48. 
największy obrońca autowtasności we wspótczesnej filozofii, stworzyt tę teorię ${ }^{41}$. Racje, które przedstawia Feser, są jednak związane z wewnętrznymi problemami każdej teorii redukcjonistycznej wygenerowanymi przez eksperymenty myślowe typu Podziat czy Teleportacja i ich konsekwencjami dla zabezpieczenia praw własności. (Dodatkowo Feser argumentuje poprzez odniesienie się do tzw. zastrzeżenia co do autowłasności w tym miejscu nie mamy jednak możliwości krytycznego odniesienia się do jego interpretacji idei self-ownership proviso).

Naszym celem nie jest jednak badanie wewnętrznych problemów teorii tożsamości/osoby (które, jak powszechnie wiadomo, nie omijają także teorii nieredukcjonistycznych), lecz zgodność tychże z zasadą autowłasności ze względu na ich strukturę logiczną; celem badawczym nie jest tu bowiem identyfikacja takiej teorii, która boryka się z najmniejszą liczbą problemów, lecz takiej, która jest koherentna z zasadą autowłasności: może być tak, że teoria tożsamości, która generuje najmniej problemów, nie jest koherentna z zasadą autowłasności, zaś ta, która jest koherentna, generuje dużą liczbę problemów, jeśli skonfrontuje się ją z nieprawdopodobnymi eksperymentami myślowymi (możliwe, że to, co dziś wydaje się nam problemem danej teorii tożsamości, zostanie w przyszłości rozwiązane przez odkrycia z dziedziny filozofii, kognitywistyki, neurologii czy neurochirurgii). Nie jest w końcu także jasne, dlaczego w przypadku konfliktu pomiędzy nieprawdopodobnymi eksperymentami myślowymi a dobrze uzasadnionymi teoriami tożsamości powinno się zawsze dawać bezwzględny priorytet tym pierwszym.

$\mathrm{Z}$ tych powodów uważamy, że podejście Fesera do pytania o kompatybilność teorii najbliższego kontynuatora z zasadą autowłasności, choć bardzo ważne i interesujące samo w sobie, de facto dotyczy nie zagadnienia koherencji pomiędzy teorią najbliższego kontynuatora a zasadą autowłasności, lecz wewnętrznych problemów teorii najbliższego kontynuatora (i innych teorii redukcjonistycznych) w radzeniu sobie z nieprawdopodobnymi eksperymentami myślowymi i konsekwencji tego stanu rzeczy dla ochrony praw własności prywatnej. Dlatego też, chociaż trudno nie zgodzić się z twierdzeniami Fesera co do problemów teorii najbliższego kontynuatora i ich konsekwencji dla ochrony praw własności, to jego tezę, jakoby teoria najbliższego kontynuatora była niekompatybilna z zasadą autowłasności, należy poddać kwalifikacji.

Zgodnie z szeroką zasadą autowłasności każdy człowiek jest właścicielem zarówno swojego ciała, jak i umysłu. Zatem człowiek - co wynika logicznie z pojęcia posiadania i własności - nie może być ani swoim ciałem, ani swoim umysłem. Skoro zaś nie może być ani swoim ciałem, ani swoim umysłem, to nie da się zredukować jego osoby/ tożsamości do żadnego z tych elementów. Osoba człowieka, jego ,ja”, jego tożsamość osobowa w czasie, to, kim jest w istocie, musi zatem być czymś więcej niż tylko zbiorem faktów mentalnych czy fizycznych; musi być czymś prostym, niepodzielnym i nieredukowalnym do zbioru faktów psychologicznych czy biologicznych, czymś wobec nich uprzednim i tłumaczącym je właśnie jako fakty odnoszące się do tej samej osoby: musi stanowić podstawę ich jedności. Szeroka zasada autowłasności presuponuje zatem nieredukcjonistyczną koncepcję osoby/tożsamości. Biorąc pod uwagę fakt, że szeroka

$41 \quad$ E. Feser, Personal Identity..., s. 116. 
zasada autowłasności praktycznie zawsze występuje także jako słaba zasada autowłasności, to znaczy odrzucająca możliwość wyzbycia się praw własności do własnego ciała i umysłu, to przyjąć należy, że związek pomiędzy jaźnią/osobą/substancją a zbiorem faktów psychologicznych i biologicznych musi być na tyle silny, iż niemożliwe jest dla jaźni/osoby/substancji wyzbycie się tychże faktów psychologicznych i biologicznych oraz związanych z nimi pozycji normatywnych (praw własności). Ta niemożliwość polegać może na tym, że wyzbywając się owych faktów i praw, jaźń/osoba/substancja przestałaby być tym, czym jest; nawet jeśli jaźń nie jest redukowalna do/nie jest żadnym zbiorem faktów psychologicznych i biologicznych oraz dotyczących ich praw, to może np. być emergentna względem owych faktów, a zatem choć jaźń nie jest zbiorem faktów psychologicznych czy biologicznych, to może być niemożliwe dla jaźni istnienie bez tych faktów. Taki stan rzeczy eliminuje ze zbioru możliwych antropologii filozoficznych libertarianizmu skrajny kartezjanizm, platonizm czy augustynizm (ogólnie rzecz biorąc, skrajny spirytualizm). Wskazuje zaś, co potwierdza główną tezę badawczą Fesera, na antropologię hylemorficzną (czyli w zależności od interpretacji umiarkowany spirytualizm bądź umiarkowany materializm) - w której związek pomiędzy osobą a zbiorem faktów psychologicznych i biologicznych jest relatywnie silny - jako na antropologię koherentną z szeroką i słabą zasadą autowłasnoścíi ${ }^{42}$. Gdyby z kolei szeroka zasada autowłasności była jednocześnie silną zasadą autowłasności, wówczas skrajny spirytualizm byłby antropologicznym horyzontem możliwości libertarianizmu, ponieważ zakłada on skrajnie słaby związek pomiędzy jaźnią a zbiorem faktów psychologicznych i biologicznych, co uzasadnia możliwość wyzbycia się praw własności do tych faktów oraz wyzbycia się umysłu i ciała.

W każdym razie, szeroka zasada autowłasności zakłada jakąś wersję nieredukcjonistycznej teorii osoby/tożsamości. Z kolei teoria najbliższego kontynuatora, jak zostało to wykazane powyżej, jest teorią redukcjonistyczną, wedle której osobę/tożsamość człowieka można sprowadzić do jakiegoś rodzaju relacji cielesnych bądź psychologicznych z dodatkiem relacji najbliższej kontynuacji. Reprezentuje więc ona przeciwstawny typ teorii osoby/tożsamości niż typ presuponowany przez szeroką zasadę autowłasności. Widać więc wyraźnie, że te dwa zespoły twierdzeń nie znajdują się w stanie równowagi refleksyjnej (nie są ze sobą koherentne). Jeśli człowiek jest autowłaścicielem w szerokim sensie, oznacza to, że musi być istotą, której jaźń jest czymś więcej niż zbiorem relacji cielesnych czy psychologicznych. Teoria najbliższego kontynuatora stoi natomiast na stanowisku, że jaźń człowieka nie jest niczym więcej niż zbiorem relacji cielesnych czy psychologicznych.

Z kolei zgodnie z wąską zasadą autowłasności każdy człowiek jest właścicielem swojego ciała, nie jest natomiast właścicielem umysłu, ponieważ przedmiotem własności mogą być tylko dobra rzadkie, a zbiory faktów mentalnych nie mają charakteru dóbr rzadkich. Zatem człowiek - co wynika logicznie z pojęcia posiadania oraz własności nie może być swoim ciałem. Może natomiast być albo swoim umysłem, czyli zbiorem

42 O nieredukcjonistycznym charakterze hylemorfizmu i pojęciu emergencji zob. E. Stump, Non- Cartesian Substance Dualism and Materialism without Reductionism, „Faith and Philosophy” 1995, Vol. 12, nr 4, s. 505-531, [online] http://dx.doi.org/10.5840/faithphil199512430. 
faktów psychologicznych, albo prostą i niepodzielną jaźnią, która choć nie jest umysłem, to nie może go także posiadać ani być jego właścicielem na mocy teorii rzadkości jako prakseologicznego warunku koniecznego istnienia kategorii własności. Istnieją więc dwie możliwe antropologie filozoficzne dla wąskiej zasady autowłasności: 1) człowiek jest w swej istocie umysłem, psychologiczną relacją $R$, czyli specyficznym zbiorem faktów psychologicznych; 2) człowiek jest jakimś rodzajem prostej i niepodzielnej substancji, nieredukowalnej ani do zbioru faktów psychologicznych, ani do zbioru faktów biologicznych. Ten drugi przypadek łączyłby się jednak z paradoksalną konsekwencją, mianowicie że człowiek, nie będąc umysłem, nie mógłby także posiadać „swojego" umysłu ani być jego właścicielem, co rodziłoby szereg poważnych pytań o relację człowieka i jego umysłu (jeśli nie jest to ani relacja tożsamości, ani posiadania, ani własności, to jaka mogłaby to być relacja?), o problem umyst-ciało czy o kwestię ciał pozbawionych świadomości. Nie wykluczając tego przypadku z antropologicznego pola możliwości wąskiej zasady autowłasności, przyjmijmy jednak, że jest on „anomalią”. Jeśli tak, oznacza to, że wąska zasada autowłasności w swej nieanomalicznej wersji presuponuje redukcjonistyczną koncepcję osoby/tożsamości, zgodnie z którą osoba/tożsamość ludzka da się zredukować do faktów mentalnych i relacji pomiędzy nimi. Z kolei teoria najbliższego kontynuatora jest teorią redukcjonistyczną, wedle której osobę/tożsamość człowieka można sprowadzić do jakiegoś rodzaju relacji cielesnych bądź psychologicznych z dodatkiem relacji najbliższej kontynuacji. Reprezentuje więc ona ten sam typ teorii osoby/tożsamości co typ zakładany przez wąską zasadę autowłasności. W tej mierze, w jakiej teoria najbliższego kontynuatora jest wariantem psychologicznej teorii tożsamości osobowej, jest ona zatem możliwą teorią tła dla wąskiej zasady autowłasności. Jeśli człowiek jest autowłaścicielem w wąskim sensie, oznacza to, że musi (biorąc w nawias przypadek anomaliczny) być istotą, której tożsamość da się sprowadzić do zbioru relacji psychologicznych, musi być wiązką faktów mentalnych i relacji między nimi.

Wbrew twierdzeniom Edwarda Fesera teoria najbliższego kontynuatora jest zatem niekompatybilna tylko z jedną możliwą wersją zasady autowłasności oraz z anomalicznym przypadkiem wersji drugiej. Nie jest natomiast niekompatybilna z każdą wersją zasady autowłasności. Jest ona koherentna z wąską zasadą autowłasności w jej nieanomalicznym wariancie. Mając to na uwadze, możemy podsumować powyższe dociekania afirmatywnie w stosunku do naszej tezy wyjściowej. A zatem, jak próbowaliśmy dowieść na kartach niniejszego artykułu, teoria najbliższego kontynuatora: 1) nie może być teorią tła dla szerokiej zasady autowłasności; 2) może natomiast być teorią tła dla wąskiej zasady autowłasności.

\section{PODSUMOWANIE ORAZ WNIOSKI DLA OGÓLNEJ ANTROPO- LOGICZNEJ TEORII TŁA ZASADY AUTOWŁASNOŚCI}

Podsumujmy na koniec związki, jakie zachodzą pomiędzy głównymi kategoriami teoretycznymi zaproponowanymi $\mathrm{w}$ niniejszym studium. Teorie redukcjonistyczne przyjmują, że osoba/tożsamość osobowa jest redukowalna do R (danego zbioru 
faktów i relacji pomiędzy nimi) w tym sensie, że osoba/tożsamość osobowa nie jest niczym więcej niż R. Teorie nieredukcjonistyczne przyjmują, że osoba/tożsamość osobowa nie jest redukowalna do $\mathrm{R} \mathrm{w}$ tym sensie, że jest czymś więcej niż $\mathrm{R}$ (nawet jeśli osoba/tożsamość osobowa posiada swoje części konstytutywne, takie jak materia i forma w hylemorficznej teorii osoby, to jest ona czymś więcej niż tylko sumą tych części konstytutywnych, np. emergentną substancją w hylemorficznej teorii osoby). Pojęcie posiadania zakłada dystans pomiędzy mna a tym, co moje, oraz związek ,ja” z tym, co moje, a nie twoje. Relacja posiadania może być silna bądź słaba na dwa sposoby. Albo dana rzecz przestaje być moja, ponieważ coraz bardziej staje się twoja, albo przestaje być moja, ponieważ coraz bardziej staje się mna. Utrata posiadania ma więc dwa wektory: dośrodkowy (ku jaźni) i odśrodkowy (od jaźni). Analogicznie pojęcie własności jako trójelementowej relacji normatywnej zakłada dystans pomiędzy mnq a tym, co moje; oraz związek ,ja” z tym, co moje, a nie twoje. Podobnież relacja własności może być silna bądź słaba na dwa sposoby. Albo dana rzecz przestaje być moja, ponieważ tracę nad nią prawa kontroli na twoją rzecz, albo przestaje być moja, ponieważ nie mogę wyzbyć się owych praw i rzecz ta coraz bardziej staje się mną. Siła relacji własności jest analitycznie wyjaśnialna za pomocą kategorii (jedenastu) praw kontroli. Im więcej praw kontroli posiadam względem danej rzeczy, tym bardziej jest ona moja; im mniej praw kontroli posiadam względem danej rzeczy, tym mniej jest ona moja, a - w zależności od wektora utraty posiadania - tym bardziej jest twoja (wektor odśrodkowy) lub tym bardziej jest mną (wektor dośrodkowy).

Szeroka i słaba zasada autowłasności przyjmuje, że jestem właścicielem ciała i umysłu. Nie jestem więc ciałem i umysłem. Muszę być czymś więcej. Oznacza to, że presuponuje ona nieredukcjonistyczną teorię osoby. Ponieważ przyjmuje ona, że podmiot nie dysponuje prawem wyzbycia się swojego ciała i umysłu, to związek między podmiotem a ciałem i umysłem jest silny, a prawo własności słabe. Odpowiada to hylemorficznej teorii osoby, w której osoba jest emergentna wobec ciała i umysłu, ale nie może bez nich istnieć - stąd też nie może się ich wyzbyć. W związku z tym hylemorficzna teoria osoby może być antropologiczną teorią tła szerokiej i słabej zasady autowłasności. Wąska zasada autowłasności przyjmuje, że jestem właścicielem tylko swojego ciała. Nie jestem więc ciałem. Mogę być bytem psychicznym, psychologicznym zbiorem/ relacją R. Oznacza to, że presuponuje ona redukcjonistyczną teorię osoby. Teoria najbliższego kontynuatora jest redukcjonistyczną teorią osoby/tożsamości. Wąska zasada autowłasności i teoria najbliższego kontynuatora są zatem koherentne. W związku z tym teoria najbliższego kontynuatora może być antropologiczną teorią tła wąskiej zasady autowłasności.

$\mathrm{Na}$ podstawie przedstawionych tu argumentów i wypracowanej siatki pojęciowej można także wyciągnąć wnioski co do ogólnych relacji teorii tożsamości/osoby z libertariańską zasadą autowłasności. Przedstawiają się one następująco:

1) Im szersza zasada autowłasności (w sensie zakresu praw własności), tym bardziej presuponuje ona nieredukcjonistyczną teorię osoby/tożsamości.

2) Im węższa zasada autowłasności, tym bardziej presuponuje ona redukcjonistyczną teorię osoby/tożsamości. 
3) Im silniejsza zasada autowłasności (w sensie praw kontroli), tym bardziej presuponuje ona spirytualistyczną teorię osoby/tożsamości.

4) Im słabsza zasada autowłasności, tym bardziej presuponuje ona materialistyczną teorię osoby/tożsamości.

\section{BIBLIOGRAFIA}

Arneson R.J., Lockean Self-Ownership: Towards a Demolition, „Political Studies” 1991, Vol. 39, nr 1, [online] http://dx.doi.org/10.1111/j.1467-9248.1991.tb00580.x.

Arneson R.J., Property Rights in Persons, „Social Philosophy and Policy” 1992, Vol. 9, nr 1, [online] http://dx.doi.org/10.1017/S0265052500003654.

Arneson R.J., SelfOwnership and World Ownership: Against Left-Libertarianism, „Social Philosophy and Policy" 2010, Vol.27, nr 1, [online] http://dx.doi.org/10.1017/S0265052509990070.

Arras J.D., The Way We Reason Now: Reflective Equilibrium in Bioethics, [w:] The Oxford Handbook of Bioethics, red. B. Steinbock, New York 2007.

Arystoteles, Metafizyka, przeł. K. Leśniak, Warszawa 2009.

Barry B., Self Ownership and the Libertarian Challenge, „Times Literary Supplement” 1996, $15 \mathrm{XI}$.

Block W., Toward a Libertarian Theory of Inalienability: A Critique of Rothbard, Barnett, Smith, Kinsella, Gordon, and Epstein, „The Journal of Libertarian Studies” 2003, Vol. 17, nr 2.

Cohen G.A., Self-Ownership, Freedom, and Equality, Cambridge 1995, Studies in Marxism and Social Theory.

Dan-Cohen M., Responsibility and the Boundaries of the Self, „Harvard Law Review” 1992, Vol. 105, nr 5 .

Dan-Cohen M., The Value of Ownership, „The Journal of Political Philosophy” 2001, Vol. 9 , nr 4.

Daniels N., Reflective Equilibrium, [w:] The Stanford Encyclopedia of Philosophy, wiosna 2011, [online] https://plato.stanford.edu/archives/spr2011/entries/reflective-equilibrium/.

Daniels N., Wide Reflective Equilibrium and Theory Acceptance in Ethics, „The Journal of Philosophy" 1979, Vol. 76, nr 5, [online] http://dx.doi.org/10.2307/2025881.

Dominiak Ł., Metoda równowagi refleksyjnej (reflective equilibrium) $w$ filozofii polityki, „Athenaeum. Polskie Studia Politologiczne" 2012, Vol. 36.

Dominiak Ł., Problem aksjomatyczności zasady autowtasności w filozofii politycznej libertariani$z m u$, „Athenaeum. Polskie Studia Politologiczne” 2016, Vol. 49.

Dworkin R., Taking Rights Seriously, London 2013, Bloomsbury Revelations.

Feser E., Personal Identity and Self-Ownership, „Social Philosophy and Policy” 2005, Vol. 22 , nr 2.

Feser E., Self-Ownership, Abortion, and the Rights of Children: Toward a More Conservative Libertarianism, „The Journal of Libertarian Studies” 2004, Vol. 18, nr 3.

Filozofia podmiotu, wybór J. Górnicka-Kalinowska, przeł. B. Chwedeńczuk i in., Warszawa 2001, Fragmenty Filozofii Analitycznej, 8.

Gorr M., Justice, Self-Ownership, and Natural Assets, „Social Philosophy and Policy” 1995, Vol. 12, nr 2, [online] http://dx.doi.org/10.1017/S0265052500004751. 
Haslett D.W., What Is Wrong with Reflective Equilibria?, „The Philosophical Quarterly” 1987, Vol. 37, nr 148, [online] http://dx.doi.org/10.2307/2220400.

Honoré A.M., Ownership, [w:] Oxford Essays in Jurisprudence (First Series), red. A.G. Guest, Oxford 1961.

Hoppe H.-H., Democracy - The God That Failed. The Economics and Politics of Monarchy, Democracy, and Natural Order, New Brunswick 2007.

Hoppe H.-H., Economic Science and the Austrian Method, Auburn 2012.

Hoppe H.-H., The Economics and Ethics of Private Property. Studies in Political Economy and Philosophy, Auburn 2006.

Hoppe H.-H., The Great Fiction. Property, Economics, Society, and the Politics of Decline, Baltimore 2012.

Hoppe H.-H., The Praxeological Foundations of Epistemology and Ethics, Qઐ A, „Austrian Economics Newsletter" 1988, Vol. 9, nr 2.

Hoppe H.-H., A Theory of Socialism and Capitalism. Economics, Politics, and Ethics, Auburn 2012, Ludwig von Mises Institute's Studies in Austrian Economics.

Juruś D., W poszukiwaniu podstaw libertarianizmu w perspektywie Rothbardowskiej koncepcji wtasności, Kraków 2012.

Kant I., Prolegomena do wszelkiej przysztej metafizyki, która będzie mogta wystąpić jako nauka, przeł. B. Bornstein, Warszawa 1960, Biblioteka Klasyków Filozofii.

Kinsella S., Against Intellectual Property, Auburn 2008.

Kinsella S., How We Come to Own Ourselves, „Mises Daily” 2006, 7 IX, [online] http://mises. org/library/how-we-come-own-ourselves.

Left-Libertarianism and Its Critics. The Contemporary Debate, red. P. Vallentyne, H. Steiner, New York 2000.

Lippert-Rasmussen K., Against Self-Ownership: There Are No Fact-Insensitive Ownership Rights over One’s Body, „Philosophy and Public Affairs” 2008, Vol. 36, nr 1, [online] http://dx.doi. org/10.1111/j.1088-4963.2008.00125.x.

Locke J., Dwa traktaty o rzadzie, przeł. Z. Rau, Warszawa 1992, Biblioteka Klasyków Filozofii.

Locke J., Rozważania dotyczace rozumu ludzkiego, t. 2, przeł. B.J. Gawecki, Warszawa 1955, Biblioteka Klasyków Filozofii.

Mack E., The Self-Ownership Proviso: A New and Improved Lockean Proviso, „Social Philosophy and Policy" 1995, vol. 12, nr 1.

McMahan J., The Ethics of Killing. Problems at the Margins of Life, New York 2002, Oxford Ethics Series.

Nozick R., Anarchy, State, and Utopia, Oxford 1999.

Nozick R., Philosophical Explanations, Cambridge 1981.

The Origins of Left-Libertarianism. An Anthology of Historical Writings, red. P. Vallentyne, H. Steiner, New York 2000.

Otsuka M., Libertarianism without Inequality, Oxford 2003.

Palmer T.G., G.A. Cohen on Self-Ownership, Property, and Equality, „Critical Review. A Journal of Politics and Society" 1998, Vol. 12, nr 3, [online] http://dx.doi.org/10.1080/ 08913819808443498.

Parfit D., Reasons and Persons, Oxford 1987. 
Pateman C., Self-Ownership and Property in the Person: Democratization and a Tale of Two Concepts, „The Journal of Political Philosophy” 2002, Vol. 10, nr 1, [online] http://dx.doi.org/ 10.1111/1467-9760.00141.

Pendlebury M., Hudson P., Moellendorf D., Capitalist Exploitation, Self-Ownership, and Equality, „The Philosophical Forum” 2001, Vol. 32, nr 3, [online] http://dx.doi.org/10. 1111/0031-806X.00062.

Rawls J., Outline of a Decision Procedure for Ethics, „The Philosophical Review” 1951, Vol. 60, nr 2, [online] http://dx.doi.org/10.2307/2181696.

Rawls J., A Theory of Justice, Cambridge 1971.

Rothbard M., The Ethics of Liberty, New York 1998.

Rothbard M., For a New Liberty. The Libertarian Manifesto, Auburn 2002.

Ryan A., Self-Ownership, Autonomy, and Property Rights, „Social Philosophy and Policy” 1994, Vol. 11, nr 2, [online] http://dx.doi.org/10.1017/S0265052500004507.

Sandel M., Liberalism and the Limits of Justice, New York 1998.

Savigny F.C. von, Das Recht des Besitzes. Eine civilistische Abhandlung, Wien 1865.

Shoemaker S., Swinburne R., Personal Identity, Oxford 1984, Great Debates in Philosophy.

Steiner H., An Essay on Rights, Oxford 1994.

Stump E., Non-Cartesian Substance Dualism and Materialism without Reductionism, „Faith and Philosophy” 1995, Vol. 12, nr 4, [online] http://dx.doi.org/10.5840/faithphil1995 12430.

Taylor R.S., Self-Ownership and the Limits of Libertarianism, "Social Theory and Practice” 2005, Vol. 31, nr 4, [online] http://dx.doi.org/10.5840/soctheorpract200531423.

Watner C., The „Criminal” Metaphor in the Libertarian Tradition, „The Journal of Libertarian Studies" 1981, Vol. 5, nr 3.

Weinberg J., Freedom, Self-Ownership, and Libertarian Philosophical Diaspora, „Critical Review. A Journal of Politics and Society" 1997, Vol. 11, nr 3, [online] http://dx.doi. org/10.1080/08913819708443464.

Wile A., Stephan Kinsella on Libertarian Legal Theory, Self-Ownership, and Drug Laws. Exclusive Interview, „The Daily Bell” 2014, 20 VII, [online] http://www.thedailybell.com/ exclusive-interviews/35492/Anthony-Wile-Stephan-Kinsella-on-Libertarian-Legal-Theory-Self-Ownership-and-Drug-Laws/.

Williams B., Problems of the Self. Philosophical Papers, 1956-1972, Cambridge 1973.

Wójcik B., Bioetyka i tożsamość cztowieka, Tarnów 2007.

Wójcik B., Śmierć mózgu jako kryterium śmierci cztowieka - problematyka filozoficzno-etyczna, „Medycyna Praktyczna” 2007, nr 4.

Wójcik B., Świadomość ponowoczesna i jej krytyka. Funkcjonalizm homunkularny w interpretacji świadomości Daniela C. Dennetta, Kraków 1997, Rozprawy OBI.

Wójcik B., Zasady zachowania tożsamości genetycznej i psychicznej jako wyróżnik bioetyki personalistycznej, „Sympozjum” 2002, Vol. 6, nr 1.

Ziemiński I., Metafizyka śmierci, Kraków 2010, Myśl Filozoficzna - WAM.

Ziemiński I., Moralność i religia. Poglądy filozoficzne Josepha Butlera, Warszawa 2015.

Ziemiński I., Życie wieczne. Przyczynek do eschatologii filozoficznej, Poznań-Kraków 2013, Wyktady Otwarte z Teologii Naturalnej im. J.M. Bochańskiego OP, 4. 
Dr Łukasz DOMINIAK - doktor nauk humanistycznych w zakresie filozofii polityki, dwukrotny stypendysta Fundacji na rzecz Nauki Polskiej w dziedzinie filozofii polityki, Summer Fellow w Mises Institute w Auburn (Alabama, Stany Zjednoczone). Redaktor naczelny periodyku „Dialogi Polityczne/Political Dialogues: Journal of Political Theory". Autor książek Wartość wspólnoty. O filozofii politycznej komunitaryzmu (2010) oraz Sprawiedliwosś - tożsamość - racjonalność. Wybrane problemy filozofii polityki (2016; wraz z Ł. Perlikowskim), a także ponad dziewięćdziesięciu innych publikacji naukowych. Adiunkt w Katedrze Hermeneutyki Polityki Wydziału Politologii i Studiów Międzynarodowych UMK w Toruniu. 